\title{
Antifungal Metabolites as Food Bio-Preservative: Innovation, Outlook, and Challenges
}

\author{
Bishwambhar Mishra ${ }^{1,+} \mathbb{D}^{\mathbb{D}}$, Awdhesh Kumar Mishra ${ }^{2,+} \mathbb{D}$, Sanjay Kumar ${ }^{3} \mathbb{D}$, Sanjeeb Kumar Mandal ${ }^{1}$, \\ Lakshmayya NSV ${ }^{1}$, Vijay Kumar ${ }^{2,4}$ D, Kwang-Hyun Baek ${ }^{2, *}$ and Yugal Kishore Mohanta ${ }^{5, *}$
}

1 Department of Biotechnology, Chaitanya Bharathi Institute of Technology, Hyderabad 500075, India; mishra.bishwambhar@gmail.com (B.M.); sanjeeb.vit@gmail.com (S.K.M.); lakshmannunna@gmail.com (L.N.)

2 Department of Biotechnology, Yeungnam University, Gyeongsan 38541, Gyeongsangbuk-do, Korea; awdhesh@ynu.ac.kr (A.K.M.); vijaykumarcbt@gmail.com (V.K.)

3 Department of Biotechnology, National Institute of Technology, Tadepalligudem, Andhra Pradesh 534101, India; sanjay0193@gmail.com

4 Department of Orthopedics Surgery, Johns Hopkins University School of Medicine, Baltimore, MD 21205, USA

5 Department of Applied Biology, University of Science and Technology Meghalaya, Ri-Bhoi 793101, India

* Correspondence: khbaek@ynu.ac.kr (K.-H.B.); yugalkmohanta@ustm.ac.in (Y.K.M.); Tel.: +82-53-810-3029 (K.-H.B.); +91-9439093024 (Y.K.M.); Fax: +82-53-810-4769 (K.-H.B.)

+ These authors contributed equally to this work.

check for updates

Citation: Mishra, B.; Mishra, A.K.; Kumar, S.; Mandal, S.K.; NSV, L.; Kumar, V.; Baek, K.-H.; Mohanta, Y.K. Antifungal Metabolites as Food Bio-Preservative: Innovation, Outlook, and Challenges. Metabolites 2022, 12, 12. https://doi.org/ 10.3390/metabo12010012

Academic Editor: Jose Lorenzo Rodriguez

Received: 13 December 2021 Accepted: 21 December 2021 Published: 23 December 2021

Publisher's Note: MDPI stays neutral with regard to jurisdictional claims in published maps and institutional affiliations.

Copyright: () 2021 by the authors. Licensee MDPI, Basel, Switzerland. This article is an open access article distributed under the terms and conditions of the Creative Commons Attribution (CC BY) license (https:// creativecommons.org/licenses/by/ $4.0 /)$.

\begin{abstract}
Perishable food spoilage caused by fungi is a major cause of discomfort for food producers. Food sensory abnormalities range from aesthetic degeneration to significant aroma, color, or consistency alterations due to this spoilage. Bio-preservation is the use of natural or controlled bacteria or antimicrobials to enhance the quality and safety of food. It has the ability to harmonize and rationalize the required safety requirements with conventional preservation methods and food production safety and quality demands. Even though synthetic preservatives could fix such issues, there is indeed a significant social need for "clean label" foods. As a result, consumers are now seeking foods that are healthier, less processed, and safer. The implementation of antifungal compounds has gotten a lot of attention in recent decades. As a result, the identification and characterization of such antifungal agents has made promising advances. The present state of information on antifungal molecules, their modes of activity, connections with specific target fungi varieties, and uses in food production systems are summarized in this review.
\end{abstract}

Keywords: anti-fungal; bio-preservation; food spoilage; perishable foods; shelf life

\section{Introduction}

The world's population is expected to reach 9.7 billion people by 2050 [1]. With the growing population, food waste and deterioration must be significantly reduced. As a result, the food business is confronting significant hurdles in meeting present and future demand. Aside from challenges such as food warehousing and distribution infrastructure, climate change impacts, and water resilience, there is far too much food waste, which encompasses livestock and crop illness.

To some extent, the food industry provides a solution through the use of admixtures such as artificial preservatives, which allow manufacturers to meet customer demands for diverse array, ease of access, price, convenience, and delivery performance while reducing the amplitude of technological treatments that results in quality losses [2]. On the other hand, consumers are not atypical in their condemnation of some food additives. Moreover, awareness among consumers about food safety and hygiene and their rejection of chemical additives has prompted research into the use of beneficial microorganisms and their metabolites as viable natural preservatives for storage stability and improved food safety. 
Managing foodborne pathogens in a wide range of food items is a significant concern for the food business, which could be solved by strategically using bio-compounds or bio-preservatives. Fungi can potentially pose important challenges during the processing of food. Deteriorative fungus plays a key role in the deterioration of perishables such as sauces, sweetened beverages, and cheese. Fungi are a common cause of food decomposition. The bulk of fungal species are saprobic, meaning they have adapted to obtain their nutrients from dead organic waste. These fungi are chemoheterotrophic, meaning they each have a set of extracellular enzymes capable of dissolving structured biopolymers during vegetative decomposition in a complex ecosystem. In food, fungi follow a similar pattern. Canonical fungal ecology, on the other hand, frequently assesses decomposition and nutrient status in complex polycultures, whilst in food processed for shelf life extension and stability, the microbial population is greatly eroded, which, when blended with commodity use performance, increases the likelihood of contamination reliant on a single main competitor [3].

Recognition of precise spoilage fungi has stepped forward substantially since the 1990s because of the arrival of molecular strategies and global taxonomic consensus. For example, identifying a restrained subset of fungi responsible for food spoilage in a particular product permits the improvement of centered prevention and intervention techniques that lessen food waste [4]. Toxicants of microbial origin, as well as disease-causing pathogens such as Salmonella, Staphylococcus aureus, Escherichia coli, Bacillus cereus, Aspergillus niger, and Clostridium perfringens, might very well pose a serious health risk to consumers [5], with admixtures posing an even greater risk [5]. Consequently, adopting naturally occurring substances not only prevents and limits the spread of undesirable bacteria but it will also enhance food quality and safety and reaffirm buyers' faith in the trustworthiness of their food [6].

Bio-preservatives are naturally occurring substances derived from plants, animals, and microbes that prolong the shelf life of food [7]. These substances suppress pathogenic organisms in food to a bare minimum or even eradicate them entirely while also improving food function and quality. Many of these chemicals are antimicrobials as well as antioxidants, and they tear down cell membranes and disrupt biosynthetic bacteria pathways [8]. The major elements of antifungal metabolites and their methods of action, interactions with their target fungi types, and their uses in food systems are highlighted in this concentrated study. The extent of prospective research directions, as well as main hurdles, are also summarized.

\section{Perishable Food Ecosystem and Microbiota}

Perishables are foods that decay, deteriorate, or become unhealthy to eat if not properly stored or devoured promptly after purchase. These foods include meat, seafood, dairy products such as milk and cheese, poultry, as well as fruits and vegetables. Once the food's usual state alters adversely, it is said to have deteriorated [9]. It could be a difference in the scent, taste, mouthfeel, or appearance of the food. The most prominent causes of rotting food are bacteria, molds, and yeasts.

\subsection{Fungal Spoiler of Foods}

The heterogeneity of fungus and yeast as culinary spoilers has been studied in many studies and food commodities. For example, fungal species, such as Saccharomyces cerevisiae in fermented products, Penicillium camemberti in mold-ripened cheeses, and Aspergillus oryzae in soy sauce, are not necessarily harmful to food production, and some are even required to provide the appropriate organoleptic features [10]. However, it is also worth remembering that a common fungus species found in fermented products can turn out to be a narrative surprise in another product.

Due to changes in $\mathrm{pH}$, carbohydrates, surface, and resistance that create ideal conditions for fungal spoilers, fruits and vegetables are particularly sensitive to mold growth throughout the maturation phase. For example, fungi cause observable signs on postharvest 
crops, such as discoloration and tissue abscess formation. Citrus, berry, stone, pome, tropi$\mathrm{cal}$, and solanaceous fruits all become spoiled due to their presence. In addition, fruit and vegetable fungal diseases have been extensively studied [11]. Rhizomes and other vegetables such as crucifers, cucurbits, bulbs, and legumes are less susceptible to fungal illnesses than fruits, possibly because their $\mathrm{pH}$ is more favorable to bacterial pathogens [12]. In addition, many of the most common postharvest illnesses are caused by fungal species from the Penicillium, Monilinia, Botrytis, Alternaria, Rhizopus, Fusarium, Aspergillus, Gloeosporium, Geotrichum, and Mucor genera [13].

Fish and milk are less prone to fungal deterioration than other animal-derived meals and raw materials, but bacterial spoilage is significantly affected. Even if the bacterial deterioration is predominated, fungal spoilage can develop in meat, especially during refrigeration [14]. Notwithstanding the need for more excellent research, black patches have been found in Penicillium, Clostridium, and Aureobasidium species, while Thamnidium spp. can generate 'whiskers' on carcasses. Yeast from the Candida, Cryptococcus, and Yarrowia species have been found on moist, packed foods, causing off-flavors and cosmetic flaws, including slime and stains [15].

\subsection{Antifungal Microorganisms in Foods}

As already mentioned, bio-preservation is gaining traction as a technique of improving food quality and safety in response to the widespread desire for less refined foods free from preservatives [16]. In recent years, many antifungal strains from a variety of microbial species have been found. They have been detected in vegetables, fruits, meat, cereals, milk and other food-related products. In addition, researchers have recently extended the isolation of new bioprotective cultures to different settings, including deep-sea and Arctic soil samples, so as to identify microorganisms potentially releasing new antifungal chemicals [17].

Antifungal activity levels and the spectrum of inhibited fungal targets differ greatly depending on the examined species and strain to strain within a species, necessitating the use of screening procedures to identify efficient antifungal microorganisms (Figure 1). For example, there was up to $75 \%$ difference across five Lactobacillus casei strains assessed for their ability to suppress the growth of four spoilage molds [18]. In another study, just a few Lactobacillus plantarum isolates out of 88 investigated showed a wide range of fungal inhibition [19]. In another investigation, only a few L. plantarum isolates out of 88 examined demonstrated a broad spectrum of fungus inhibition [20]. Another study found that 55 yeast isolates from the skin of grape varieties (Aureobasidium pullulans, Cryptococcus magnus, Candida zeylanoides, Pseudozyma aphidis, Candida sake, Hanseniaspora uvarum, Rhodotorula mucilaginosa) could hinder Aspergillus tubingensis cell growth, with a 58\% inhibition.

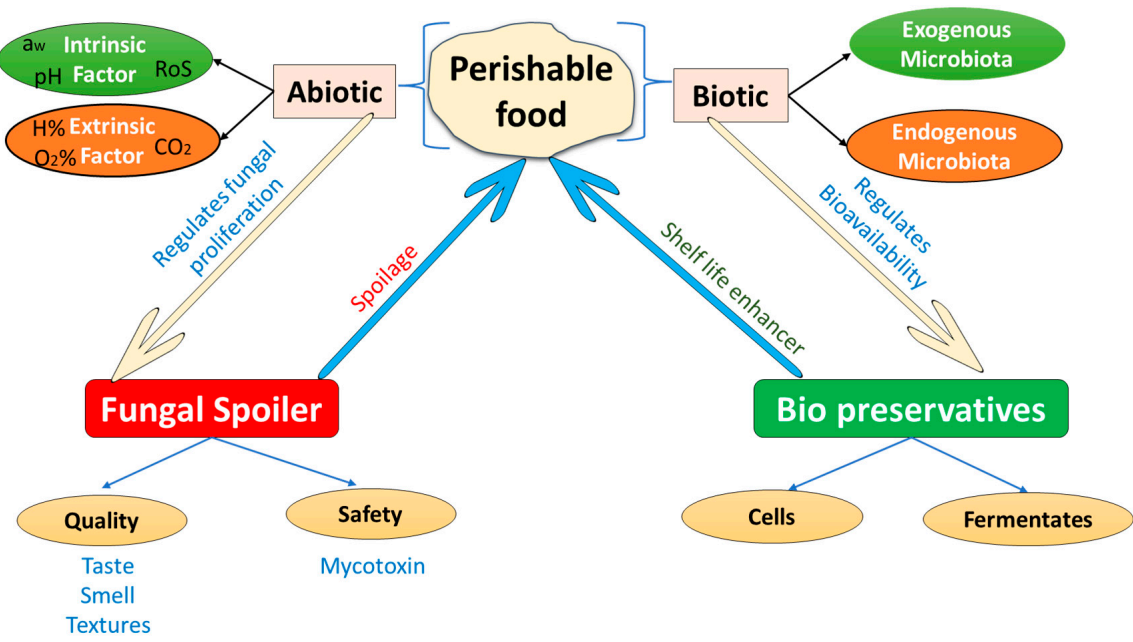

Figure 1. Schematic representation of perishable food ecosystem and their interaction between food spoilers and bio-preservatives. 


\section{Classification of Antifungal Metabolites Found in Food Habitats}

Metabolites that can control the fungal infection or disease are categorized as antifungal metabolites. These metabolites are produced and accumulated by a wide range of bacterial and fungal species, actinomycetes, and plants. Several genera of lactic acid bacteria (LAB) have been reported to produce various antifungal compounds, viz. phenyllactic acids, fatty acids, organic acids, reuterin, cyclic dipeptides, diacetyl, hydrogen peroxide, lactones, and alcohols [21]. There are various groups of antifungal metabolites found in food habitats, as follows.

\subsection{Organic Acids}

Organic acids have been utilized for several years to prevent microbial growth in food products such as bread and sausages [22,23], milk and milk-based products [24], meat and poultry products [25], and fruits and vegetables [26,27]. A few examples of major organic acids used as antifungal agents which target various fungal species are described in Table 1.

Table 1. Major organic acids as an antifungal agent and targeted fungal strain.

\begin{tabular}{|c|c|c|c|c|}
\hline Source of Organic Acid & Organic Acid & Microbial Target & Primary Food Products & References \\
\hline Lactobacillus brevis AM7 & $\begin{array}{l}\text { Lactic acid, } \\
\text { Acetic acid }\end{array}$ & $\begin{array}{l}\text { Penicillium roqueforti } \mathrm{P} 1 \text {, } \\
\text { Eurotium herbariorum CBS } \\
117336 \text { and Penicillium } \\
\text { albocoremium CBS } 109582\end{array}$ & Bread & {$[22]$} \\
\hline $\begin{array}{c}\text { Lactobacillus paracasei } \\
\text { subsp. paracasei SM20, } \\
\text { Propionibacterium jensenii } \\
\text { SM11 }\end{array}$ & $\begin{array}{c}\text { Propionic acid, } \\
\text { 2-pyrrolidone-5-carboxylic acid, } \\
\text { Acetic acid, } \\
\text { Lactic acid, } \\
\text { 3-phenyllactic acid, } \\
\text { Hydroxyphenyllactic acid, } \\
\text { Succinic acid }\end{array}$ & Spoilage yeasts and molds & $\begin{array}{c}\text { Yoghurt and cheese } \\
\text { surfaces }\end{array}$ & {$[28]$} \\
\hline $\begin{array}{c}\text { Pseudomonas fluorescens } \\
\mathrm{ZX}\end{array}$ & $\begin{array}{l}\text { Butyric acid, } \\
\text { Acetic acid, } \\
\text { Isobutyric acid, } \\
\text { 2-Methylbutyric acid, } \\
\text { 3-Methylbutyric acid }\end{array}$ & Penicillium italicum & Citrus fruits & [29] \\
\hline $\begin{array}{l}\text { Seeds of Cuminum } \\
\text { cyminum L. }\end{array}$ & Cuminic acid & $\begin{array}{c}\text { Fusarium oxysporum f. sp. } \\
\text { niveum }\end{array}$ & $\begin{array}{l}\text { Horticultural crops, } \\
\text { watermelon }\end{array}$ & {$[30]$} \\
\hline $\begin{array}{l}\text { Acetylation reaction of } \\
\mathrm{CH}_{3} \mathrm{COOH} \text { with } \mathrm{H}_{2} \mathrm{O}_{2}\end{array}$ & Peracetic acid & $\begin{array}{c}\text { Aspergillus flavus, } \\
\text { Penicillium verrucosum }\end{array}$ & Maize and barley grain & {$[31]$} \\
\hline $\begin{array}{l}\text { Bacillus cereus, } \\
\text { B. subtilis } \\
\text { B. mojavensis, } \\
\text { B. velezensis }\end{array}$ & Indoleacetic acid & Fusarium equiseti & Vicia faba & {$[32]$} \\
\hline $\begin{array}{l}\text { Lactobacillus plantarum } \\
\text { IS10, } \\
\text { L. brevis NCDC 02, } \\
\text { L. paracasei M3 }\end{array}$ & $\begin{array}{c}\text { 5-Oxopyrrolidine-2-carboxylic acid, } \\
\text { 3-(4-Hydroxyphenyl) propanoic acid, } \\
\text { 3-Phenylpropanoic acid, } \\
\text { Hydroxyphenyllactic acid, } \\
\text { Dodecanoic acid }\end{array}$ & Mucor, Penicillium & $\begin{array}{l}\text { Yoghurt, cheese, sour } \\
\text { cream }\end{array}$ & {$[33]$} \\
\hline $\begin{array}{c}\text { Lactobacillus fermentum } \\
\text { YML014 }\end{array}$ & $\begin{array}{l}\text { Lactic acid, } \\
\text { Acetic acid }\end{array}$ & $\begin{array}{c}\text { Aspergillus niger, } \\
\text { A. flavus, } \\
\text { Candida albicans, } \\
\text { Penicillium expansum, } \\
\text { Zygosaccharomyces rouxii }\end{array}$ & $\begin{array}{l}\text { Fermented } \\
\text { vegetables }\end{array}$ & {$[34]$} \\
\hline $\begin{array}{l}\text { Penicillium chrysogenum } \\
\text { CECT } 20922\end{array}$ & $\begin{array}{l}\text { Hexanoic acid } \\
\text { Octanoic acid }\end{array}$ & $\begin{array}{c}\text { Cladosporium } \\
\text { cladosporioides, } \\
\text { C. herbarum, C. oxysporum }\end{array}$ & $\begin{array}{c}\text { Meat, } \\
\text { dry-cured fermented } \\
\text { sausages }\end{array}$ & {$[23,35]$} \\
\hline
\end{tabular}

\subsection{Phenyllactic Acid (PLA)}

Phenyllactic acid is a natural bioactive compound, having a broad-spectrum inhibitory activity against a few bacteria (Enterococcus spp., Listeria monocytes, Salmonella spp., Staphylococcus aureus, etc.), fungi, molds, and yeast (Candida and Rhodotorula spp.) [36]. 
Typically, PLA is obtained from LAB such as Lactobacillus, Weissella, and Leuconostoc through phenylalanine metabolism. In this process, aromatic aminotransferase enzyme transaminates phenylalanine to phenylpyruvic acid (PPA), which is further reduced to PLA by lactate dehydrogenase enzyme $[37,38]$. LAB inhibits undesirable microbial and fungal growth by reducing the $\mathrm{pH}$ level in the system. Hence, PLA produced by LAB improves food safety with increased shelf life of food products, which subsequently positively impacts consumers' health. Therefore, PLA has been widely accepted as a natural preservative in the food industry $[39,40]$. A few examples related to the sources of PLA and their antifungal activity against a broad spectrum of microbes along with the associated food products are described in Table 2.

Table 2. Phenyllactic acid-producing source and its targeted fungal strain.

\begin{tabular}{|c|c|c|c|}
\hline Source of PLA & Microbial Target & Primary Food Products & References \\
\hline Latobacillus crustorum & Broad range of bacterial and fungal species & $\begin{array}{l}\text { Naturally fermented Chinese } \\
\text { vegetable }\end{array}$ & [37] \\
\hline $\begin{array}{c}\text { Lactobacillus brevis, } \\
\text { L. plantarum, } \\
\text { L. sakei, } \\
\text { Leuconostoc lactis, } \\
\text { Leuconostoc mesenteroide, } \\
\text { Pediococcus pentosaceus, }\end{array}$ & $\begin{array}{c}\text { Aspergillus, } \\
\text { Penicillin spp., } \\
\text { Candida, } \\
\text { Rhodotorula spp. }\end{array}$ & $\begin{array}{l}\text { Kimchi (a fermented vegetable food } \\
\text { product in Korea) }\end{array}$ & [41] \\
\hline $\begin{array}{l}\text { Lactobacillus plantarum KP3 } \\
\text { L. plantarum KP4 }\end{array}$ & $\begin{array}{l}\text { Gram-positive/negative bacteria and some } \\
\text { fungal species }\end{array}$ & Porphyra residues & [42] \\
\hline Lactobacillus sp. MX3.2 & $\begin{array}{c}\text { Aspergillus niger, A. flavus, A. oryzae, } \\
\text { E. coli, } \\
\text { Salmonella enterica, Shigela flexneri }\end{array}$ & Mango and chilli & [43] \\
\hline $\begin{array}{l}\text { Lactobacillus plantarum } \\
\text { argentoratensis, } \\
\text { Enterococcus faecium }\end{array}$ & Aflatoxigenic fungi & Agricultural commodities & [44] \\
\hline Lactobacillus buchneri GBS3 & $\begin{array}{l}\text { Aspergillus, Penicillium, } \\
\text { Fusarium species }\end{array}$ & Traditional Chinese pickles & [38] \\
\hline Lactobacillus plantarum dy-1 & Broad spectrum of fungi & Fermented barley extracts & [45] \\
\hline $\begin{array}{l}\text { Lactobacillus kefiri M4, } \\
\text { Pediococcus acidilactici MRS-7 }\end{array}$ & Penicillium expansum & Fruits & [46] \\
\hline Lactobacillus plantarum & Fusarium oxysporum, F. fujikuroi & Crops & [47] \\
\hline $\begin{array}{l}\text { Lactobacillus brevis, } \\
\text { L. plantarum }\end{array}$ & Phytophthora infestans & Fermented green olives & [48] \\
\hline $\begin{array}{l}\text { Lactobacillus brevis, } L \text {. plantarum, } L . \\
\text { pentosus }\end{array}$ & $\begin{array}{c}\text { Fungi (Candida pelliculosa and Penicillium } \\
\text { digitatum) } \\
\text { Molds (Penicillium sp, Aspergillus niger, } \\
\text { Rhizopus sp., Fusarium oxysporum), } \\
\text { Yeasts (Candida pelliculosa and Rhodotorula sp.), }\end{array}$ & Fermented green olives & [49] \\
\hline $\begin{array}{l}\text { Lacticaseibacillus spp. and } \\
\text { Lactiplantibacillus spp. }\end{array}$ & $\begin{array}{c}\text { Debaryomyces hansenii, Torulaspora delbrueckii, } \\
\text { Meyerozyma guilliermondii }\end{array}$ & Cottage cheese & [50] \\
\hline Lactobacillus reuteri $\mathrm{R} 29$ & Fusarium culmorum & Bread system & [51] \\
\hline Pediococcus acidilactici CRL 1753 & $\begin{array}{c}\text { Aspergillus niger } \mathrm{CH} 2, \\
\text { Candida tropicalis } \mathrm{CH6}, \\
\text { Penicillium roqueforti } \mathrm{CH} 4, \\
\text { Metschnikowia pulcherrima } \mathrm{CH} 7\end{array}$ & Bread & [52] \\
\hline $\begin{array}{l}\text { Lactobacillus plantarum TR7, } \\
\text { L. plantarum TR71 }\end{array}$ & Penicillium expansum, Aspergillus flavus & Tomato & [53] \\
\hline Lactobacillus plantarum & Aspergillus fumigatus, Penicillium roqueforti & Chinese pickles & [54] \\
\hline Lactobacillus hammesii & $\begin{array}{l}\text { Aspergillus niger, } \\
\text { Penicillium roqueforti }\end{array}$ & Wheat bread & [55] \\
\hline Lactobacillus plantarum CRL 778 & Aspergillus niger & Fermented foods & [56] \\
\hline $\begin{array}{l}\text { Lactobacillus fermentum, } \\
\text { L.plantarum }\end{array}$ & Aspergillus and Penicillium genera & Fermented and dried cocoa beans & [57] \\
\hline
\end{tabular}




\subsection{Fatty Acids}

Fatty acids are accumulated by a broad spectrum of microbes (such as bacteria, actinomycetes, and fungi) as well as plants. Various literature has revealed that fatty acids have been used as an active antimicrobial agent against a wide range of food spoilage bacteria, molds, and yeast [58-60]. A study [61] highlighted the correlations between the configurations of hydroxy unsaturated fatty acids (HUFA) and their associated antifungal activities. This study also exhibited that the 18-carbon unsaturated fatty acid chains having the hydroxyl group in the center's proximity showed intense antifungal activity [61]. Similarly, Souza et al. [62] explained the antifungal activity against Candida species concerning change in the structure of aliphatic fatty acids. They also described that the structure of each fatty acid strongly affects its antifungal activity. The antifungal activity is strongly affected by the carbon chain length; for example, an increase in carbon chain length reduces the antifungal activity of fatty acids (and vice versa), whereas medium chain length fatty acids usually reveal the maximum antifungal activity [62]. Furthermore, the hydroxyl group was found to be essential for antifungal activity. It was also reported that the capric and lauric acids had shown the best anti-Candida results.

Elsherbiny et al. [63] studied the anti-Penicillium effect of $\beta$-aminobutyric acid (BABA) in orange fruit. They reported that the concentration of BABA plays a crucial role in the inhibition of fungal growth; for example, growth of fungal strain was significantly inhibited by $125 \mathrm{mM}$ of BABA. Pinilla et al. [64] examined the antifungal property of oleic acid through liposomes of oleic acid (OA) and phosphatidylcholine (PC) encapsulating garlic extract (GE). It showed great potential for controlling fungal growth in wheat bread. Lactobacillus sp. RM accumulate 6-octadecenoic acid and hexadecanoic acid as a secondary metabolite, which is reported as an effective antifungal agent against mycelia of Aspergillus parasiticus [65]. 3-Hydroxy-5-dodecenoic acid causes severe damage to the surface of Bacillus cereus and leads to a decrease in the endospore size of the cell. Solano et al. [58] reported that the intermediate concentration of lauric acid exhibited strong antifungal activity against Colletotrichum tamarilloi.

\subsection{Reuterin}

Reuterin (3-hydroxy propionaldehyde or 3-HPA) is a non-proteinaceous and watersoluble antimicrobial agent produced by Lactobacillus reuteri [66]. Other genera of bacteria have produced it, including Citrobacter, Bacillus, Klebsiella, Enterobacter, and Clostridium [67]. Reuterin was reported to be produced during the anaerobic metabolism of glycerol (Vollenweider and Lacroix, 2004). Reuterin can work over a broad range of $\mathrm{pH}$ and remain active in the presence of various enzymes [68]. Therefore, reuterin was reported as a potential antibacterial and antifungal agent against a broad spectrum of microbes and utilized as a food preservative in the food industry [69]. Several inhibitory activities of reuterin have been investigated against a broad spectrum of microbes. However, the studies related to the antifungal activity of reuterin are limited as the inhibiting lead molecules present in reuterin have not yet been investigated so far.

A study on minimum fungicidal activity and inhibitory activity of reuterin against a group of fungi and yeast species reported that the reuterin produced by Lactobacillus reuteri ATCC 53608 showed the inhibition of growth of food spoilage microorganisms at a concentration of $11 \mathrm{mM}$ or less. Additionally, reuterin also exhibited a fungicidal activity (99.9\%) at concentrations equal to or below $15.6 \mathrm{mM}$ [67]. At the same time, another study reported that the reuterin was an effective antimicrobial agent against Lactobacillus delbrueckii sp. Bulgaricus, Penicillium expansum, Listeria monocytogenes, Staphylococcus aureus, and Escherichia coli DH5 $\alpha$ microorganisms. There are few microorganisms that are highly resistant (Lactobacillus reuteri ATCC 53608), and few are susceptible (E. coli DH5 $\alpha$ ) to reuterin [69]. 


\subsection{Cyclic Dipeptides (CDP)}

Cyclic dipeptides are the secondary metabolites that have been isolated from several species of bacteria [70], such as Bacillus cereus subsp. thuringiensis [71], Lactobacillus plantarum [72], and Bacillus velezensis AR1 [73]. CDPs are active at higher temperatures and resistant to denaturation by hydrolytic enzymes [74]. Individual CDPs worked as bio-effectors, whereas pooled CDPs have shown potential bioactive properties against numerous pathogens. In addition to that, the combination of CDPs in the presence or absence of antibiotics may exert collaborative antimicrobial properties [75]. As an antimicrobial function, CDPs may decrease the mycelial growth, alter the nuclear DNA functionally and structurally, make the mold membrane porous, inhibit ergosterol synthesis, alter the osmotic equilibrium, and initiate the oxidative apoptotic stress [76]. Thus far, various studies have been conducted to identify the newer CDPs as potential antifungal agents and antibacterial agents. Recent investigations on CDPs as having potential antifungal agents are described in Table 3.

Table 3. Cyclic dipeptides identified as antifungal agents.

\begin{tabular}{|c|c|c|c|}
\hline Sources of CDP & Identified CDP & Microbial Target & References \\
\hline Lactococcus lactis subsp. cremoris & cyclo(Leu-Pro) & Fungal Species & [77] \\
\hline Aciculosporium take & $\begin{array}{l}\text { cyclo(L-pro-L-Phe), } \\
\text { cyclo L-pro-L-Leu), } \\
\text { cyclo(L-pro-L-Ile) }\end{array}$ & Fungal species & [78] \\
\hline Epicoccum nigrum $\mathrm{M} 13$ & $\begin{array}{c}\text { cyclo(L-Pro-L-Ile), } \\
\text { cyclo(L-Pro-L-Val), } \\
\text { cyclo(L-Pro-L-Tyr), cyclo(L-Pro-L-Phe), }\end{array}$ & Fungal and bacterial species & [79] \\
\hline Bacillus amyloliquefaciens Q-426 & $\begin{array}{l}\text { cyclo(L-Pro-L-Phe), cyclo(L-Pro-D-Phe), } \\
\text { cyclo(D-Pro-D-Phe), } \\
\text { cyclo(D-Phe-L-Pro) }\end{array}$ & Broad range of fungi & [80] \\
\hline $\begin{array}{l}\text { Bacillus amyloliquefaciens subsp. } \\
\text { plantarum strain FZB42 }\end{array}$ & $\begin{array}{l}\text { cis-cyclo(L-Pro-L-Ile), } \\
\text { cis-cyclo(L-Pro-L-Leu), } \\
\text { cis-cyclo(L-Pro-L-Phe), } \\
\text { cis-cyclo(L-Pro-L-Pro), } \\
\text { cis-cyclo(L-Pro-L-Val), }\end{array}$ & Filamentous fungi & [74] \\
\hline Bacillus velezensis AR1 & 5-N-tyrosinylornithine & $\begin{array}{l}\text { Monilinia fructicola and } \\
\text { Colletotricum goeosporioides }\end{array}$ & [73] \\
\hline $\begin{array}{l}\text { Prenylation of tryptophan with } \\
\text { cyclic dipeptides at C7 position by } \\
\text { 7-Dimethylallyl }\end{array}$ & $\begin{array}{c}\text { cyclo(L-Trp-Gly), } \\
\text { cyclo(L-Trp-L-Ala), } \\
\text { cyclo(L-Trp-L-Phe), } \\
\text { cyclo(L-Trp-L-Leu), } \\
\text { cyclo(L-Trp-L-Pro), cyclo(L-Trp-L-Trp), } \\
\text { cyclo(L-Trp-L-Tyr) }\end{array}$ & $\begin{array}{c}\text { Aspergillus flavus, Candida } \\
\text { albicans, } \\
\text { Fusarium oxysporum, } \\
\text { Alternaria brassicae, } \\
\text { Rhizoctonia solani, } \\
\text { Penicillium expansum }\end{array}$ & [81] \\
\hline Pediococcus pentosaceus & Hexahydro-7-hydroxy-phenylmethyl & Aspergillus niger & [82] \\
\hline Lactobacillus rhamnosus & $\begin{array}{l}\text { 9-amino acid peptide (a derivative of } \\
\alpha_{\mathrm{s} 2 \text {-casein) }}\end{array}$ & $\begin{array}{c}\text { Mucor racemosus, } \\
\text { Rhodotorula mucilaginosa }\end{array}$ & [60] \\
\hline Paenibacillus sp. MS2379 & $\begin{array}{l}\text { Fusaricidins along with amino acid } \\
\text { residues of } \gamma \text {-aminobutyric acid } \\
\text { and serine }\end{array}$ & Broad array of fungal pathogens & [83] \\
\hline Lactobacillus plantarum LBPK10 & $\begin{array}{c}\text { cyclo(Val-Pro), } \\
\text { cyclo(Tyr-Pro), cyclo(Ser-Pro), }\end{array}$ & Broad range of fungal species & [84] \\
\hline Lactobacillus plantarum LBPK10 & $\begin{array}{l}\text { cis-cyclo(L-Leu-L-Hyp), } \\
\text { cyclo(Phe-Pro), } \\
\text { cyclo(Leu-Pro) }\end{array}$ & $\begin{array}{l}\text { Bacterial, virus and fungal } \\
\text { pathogen. }\end{array}$ & [84] \\
\hline
\end{tabular}


Table 3. Cont.

\begin{tabular}{|c|c|c|c|}
\hline Sources of CDP & Identified CDP & Microbial Target & References \\
\hline $\begin{array}{c}\text { Lactobacillus casei AST18, L. } \\
\text { plantarum AF1, L. Plantarum } \\
\text { MiLAB 393, }\end{array}$ & $\begin{array}{c}\text { 2,6-diketopiperazines and their } \\
\text { derivatives, } \\
\text { 2,5-diketopiperazines, } \\
\text { 2,3-diketopiperazines }\end{array}$ & $\begin{array}{c}\text { Fungi and } \\
\text { Gram-positive/negative } \\
\text { bacteria }\end{array}$ & {$[85]$} \\
\hline Pediococcus pentosaceus & Non-pediocin-like peptides & Fusarium graminearum & {$[76]$} \\
\hline Bacillus cereus subsp. thuringiensis & $\begin{array}{l}\text { cyclo(D-Pro-L-Met) } \\
\text { cyclo(D-Pro-D-Tyr) }\end{array}$ & $\begin{array}{c}\text { Rhizoctonia solani, Fusarium } \\
\text { oxysporum, Penicillium expansum }\end{array}$ & {$[71]$} \\
\hline Lactobacillus plantarum & $\begin{array}{l}\text { cyclo(Tyr-Pro), } \\
\text { cis-cyclo(L-Leu-L-Pro), } \\
\text { cis-cyclo(L-Val-L-Pro), } \\
\text { cis-cyclo(L-Phe-L-Pro) }\end{array}$ & $\begin{array}{l}\text { Broad spectrum of fungi, } \\
\text { bacteria, and virus }\end{array}$ & {$[72]$} \\
\hline Bacillus spp. & $\begin{array}{l}\text { cyclo(L-Pro-L-Tyr), } \\
\text { cyclo(D-Pro-L-Leu), } \\
\text { cyclo(L-Pro-L-Met), } \\
\text { cyclo(D-Pro-L-Phe), } \\
\text { cyclo(L-Pro-D-Tyr), } \\
\text { cyclo(L-Pro-L-Phe) }\end{array}$ & $\begin{array}{l}\text { Rhizoctonia solani, } \\
\text { Aspergillus flavus, } \\
\text { Candida albicans, } \\
\text { Penicillium expansum, } \\
\text { Fusarium oxysporum }\end{array}$ & {$[86]$} \\
\hline
\end{tabular}

\subsection{Miscellaneous Antifungal Compounds}

Although organic acids, phenyllactic acid, fatty acids, reuterin, and cyclic dipeptides are the major antifungal compounds synthesized and accumulated by a range of microbial strains associated with food habitat, a few other compounds of microbial origin (such as nisin, lactocin, divergicin and hydrogen peroxide) were also reported as potential antifungal agents [87]. In addition to that, some other antifungal compounds are also being reported to be accumulated as well as plants. Caffeic acid and rosmarinic acid extracted from Lamiaceae herbs showed strong antifungal activity against the Fusarium oxysporum $\mathrm{f}$. sp. Cyclaminis [88]. Essential oils are volatile substances and are naturally produced by plants as secondary metabolites. These are known for their antifungal, insecticidal, and antibacterial properties. The essential oils extracted from spices (garlic and clove) showed antimicrobial activity against fungal pathogens such as Candida albicans, C. catenulate, C.acutus, C. apicola, C. tropicalis, C. inconspicua, Trigonopsis variabilis, Rhodotorula rubra, and Saccharomyces cerevisiae [89].

\section{Mode of Action for Various Metabolites}

As mentioned in the previous section, we have many diversified categories of antifungal metabolites ranging from organic acids to modified PLA, along with several substances such as reuterin, cyclic dipeptides, etc. Though they prove their efficacy and efficiency in various ways, they might involve chemical treatment at some of the other stages. Although they have limited side effects, they could be significant in the long run and with prolonged usage. Although biosynthesis proves to be a promising alternative for these chemical substances, this approach may not exactly resemble the chemical counterpart of the same. However, we can overcome this barrier by looking onto natural derivatives rather than a natural way of synthesizing the chemical components. This section highlights several aspects of biosynthesis, derivation as well as mechanisms [90,91].

\subsection{Citric Acid and Phenyllactic Acid}

Among the many organic acids (which are generally weak acids), citric acid shows as high as $80 \%$ antifungal properties. Citric acid can be biosynthesized using fungal fermentation, either liquid surface fermentation or submerged fermentation. The ability of citric acid to inhibit mycelial growth proves its efficacy as an antifungal agent (Figure 2) [92]. Because of their solubility, flavor-enhancing qualities, and low toxicity, organic acids are 
commonly utilized as antibacterial or acidulant preservatives in the food industry. Sorbic acid and its sodium, potassium, and calcium salts are widely used as powerful antifungal and antibacterial agents, extending the shelf life of food goods.

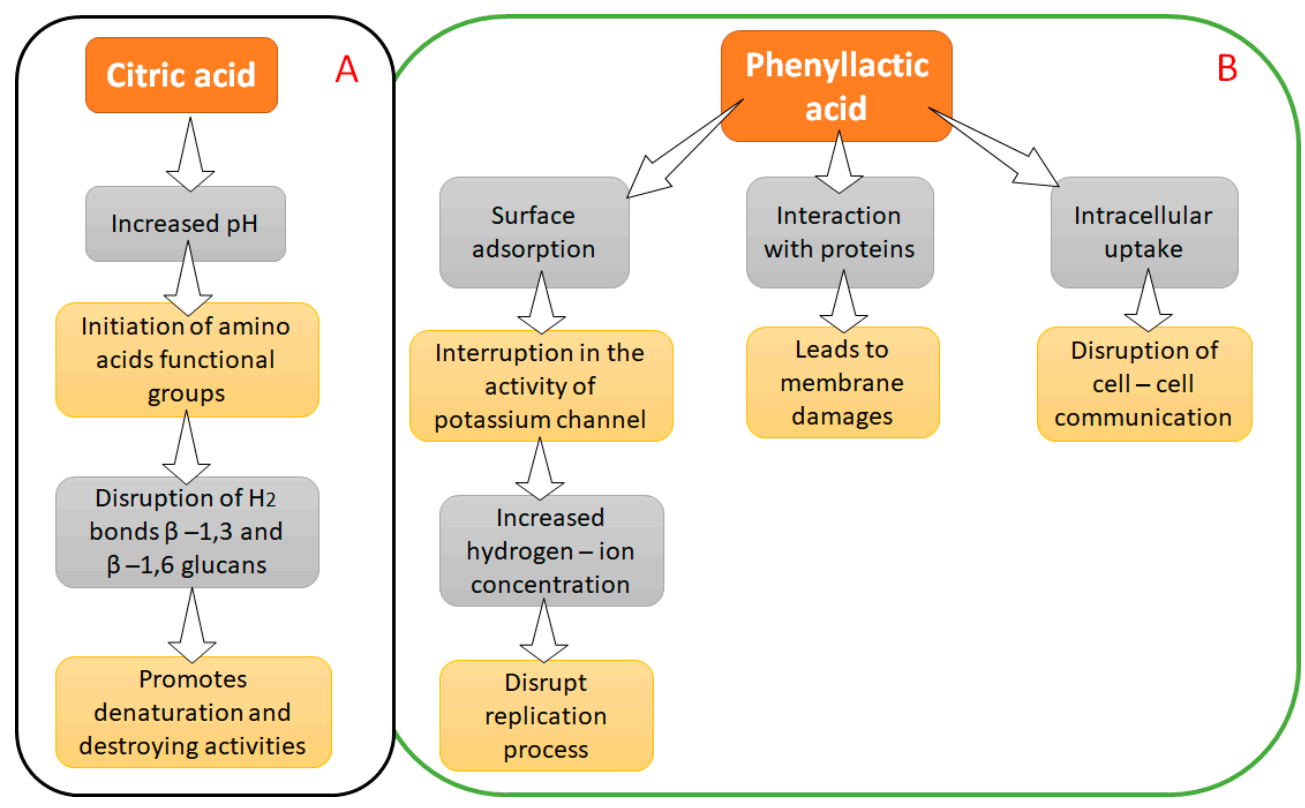

Figure 2. Mechanism of organic acids ((A) for Citric acid; (B) Phenyllactic acid) as bio-preservatives.

Organic acids producing bacteria comprise the larger class of LAB (lactic acid bacteria), which have been used in the food industry for a long time. Organic acids are extensively synthesized from lactic acid bacterial species such as, Pediococcus acidilactici which can be cultivated in labs or even found in traditional Chinese medicines [93]. The whole class of LAB shows a wide range of mechanisms depending upon the species used as an antifungal agent. This broad spectrum includes increased oxidative stress and cell permeability, enzyme inhibition, proton gradient interference, etc. [94,95]. Phenyllactic acids (PLA) (also called 3-Phenyl lactic acid or 2-Hydroxy-3-Phenylpropionic acid) inhibited Penicillium roqueforti, Aspergillus ochraceus, Fusarium graminearum, Penicillium expansum, Aspergillus niger, Monilia sitophila, Aspergillus flavus, Penicillium verrucosum, Penicillium citrinum, and other fungi [96]. In a study, PLA had a minimum inhibitory concentration (MIC) of $6.5-12.0 \mathrm{mg} / \mathrm{mL}$ against fungus [20]. The mechanism of the antifungal activity of PLA is poorly understood. Various researchers have suggested that PLA interferes with the proton gradient and inhibits cellular enzymes, often coactively working with other metabolites [97]. PLA's antifungal activities are thought to be inhibiting fungal radial growth and sporulation. PLA also inhibited the development and sporulation of fungal radicals on malt extract agar [98].

\subsection{Essential Oils and Phytochemicals}

Essential oils are the substances released by plants as a defense mechanism against extraneous factors. They can be easily extracted from various parts of plants such as flowers, stems, roots, leaves, etc. They have also been used as perfumery agents for centuries. Though the number of EOs produced by plants is relatively high, it would be a sophisticated process to characterize every EO, synthesis, and mechanism. Therefore, a few of them have been summarized in Figure 3 below [99]. 


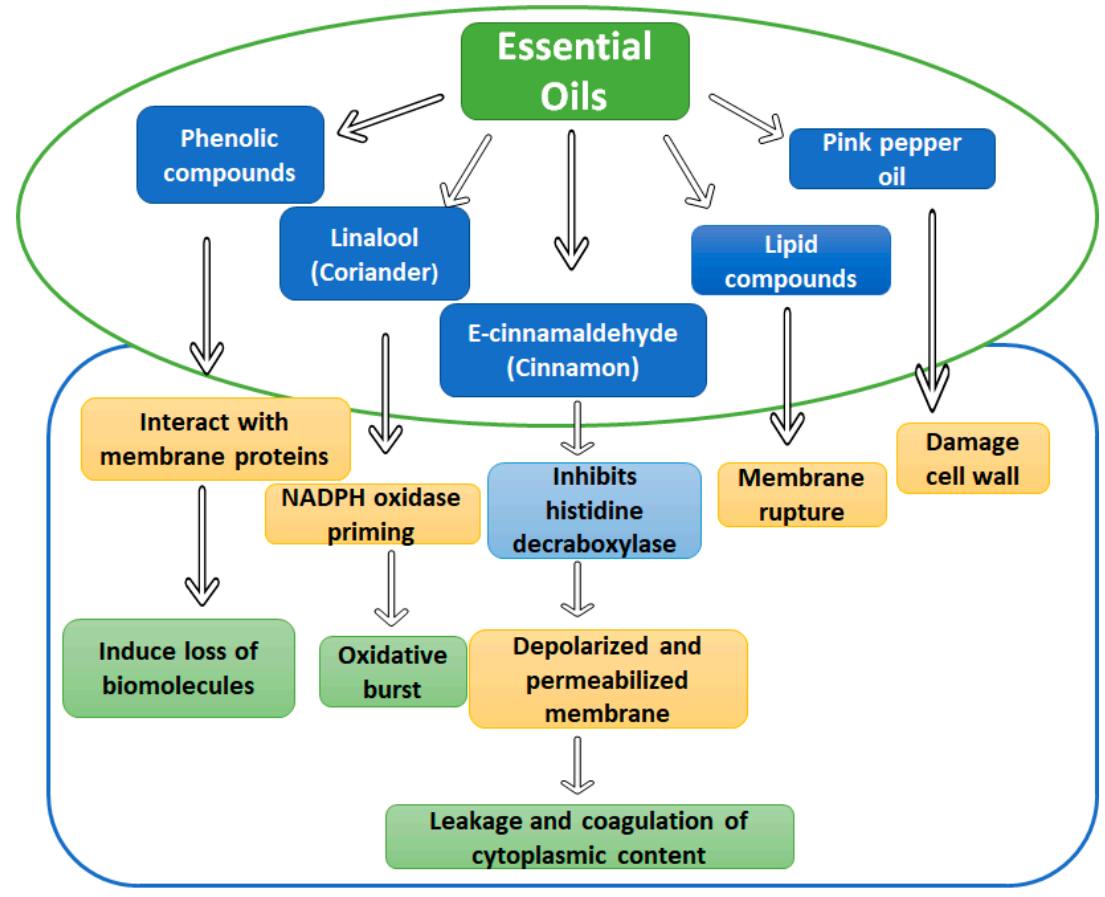

Figure 3. Mechanism of various essential oils as bio-preservatives.

Terpenes are the most diverse category of chemical compounds identified in plant extracts, with significant antifungal action that can be boosted synergistically by the presence of additional phytochemicals (Figure 4). Grifolin, a sesquiterpene chemical derived from the fruiting bodies of the fungus Albatrellus dispansus, inhibits the mycelial growth of plant pathogenic fungi such as Sclerotinina sclerotiorum, as well as spore germination on Fusarium graminearum, Pyricularia oryzae and Gloeosporium fructigenum [100]. Catechins were shown to rupture the fungal membrane by binding to the ergosterol layer and inhibiting the intracellular and extracellular enzymes [101]. On the other hand, Quercetin proves its antifungal activity by decreasing protein motive forces, thereby increasing membrane permeability [102]. Kaemferol works by blocking the QS pathway, which leads to failure of the cell-to-cell communication which ultimately prevents biofilm formation [103].

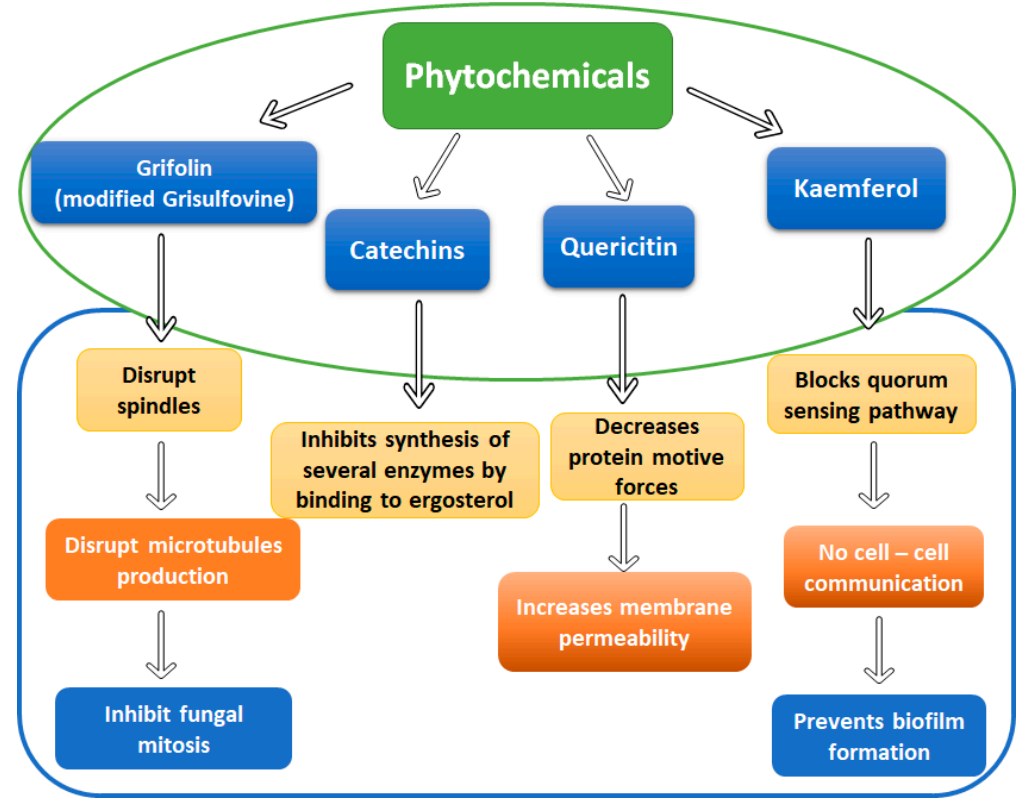

Figure 4. Mechanism of various phytochemicals as bio-preservatives. 


\subsection{Azoles}

Azoles are another class of excellent antifungal agents, which target the fungal cell membrane by acting as competitive inhibitors for CYP51 (a cytochrome P450 enzyme). CYP51 plays a vital role in ergosterol biosynthesis (which is the main component of the fungal cell wall). In addition, the class of azoles includes various sub-components acting as potential antifungal agents that can be categorized based upon their targeting molecules (Figure 5) [104].

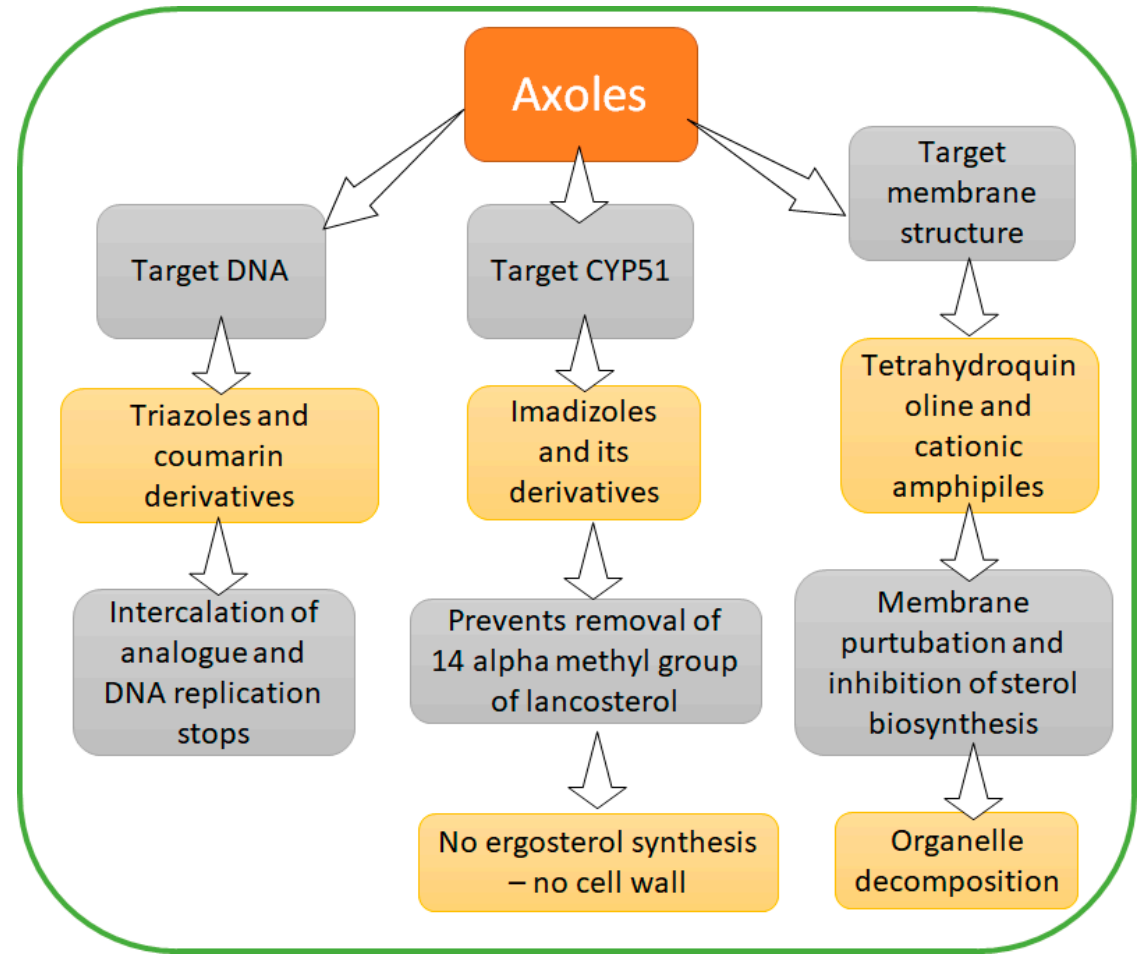

Figure 5. Mechanism of azoles as bio-preservatives.

\section{Applications Oriented Studies from Laboratory to Pilot Scale}

Conventional suspensions prepared from phytocompounds have antifungal effects. The antifungal range of a nanoemulsion made by ultrasonication using Cleome viscosa essential oil and Triton-x-100 was studied. Essential oil nanoemulsion (EONE) was evaluated with foodborne pathogenic Candida albicans at a minimum inhibitory and fungicidal dosage. The MIC and MFC values for C. albicans isolates ranged from 16.5 to $33 \mathrm{~mL} / \mathrm{mL}$, with a considerable reduction in biofilm. Fourier transformed infrared spectroscopy corroborated the shift in compositional fingerprinting, and spectroscopic analysis revealed a drop in chitin levels in cell walls. In C. albicans cells, EONE and its biologically active compounds cause massive damage [105].

Several techniques have proven that the primary components of EOs have antioxidant, antibacterial, and antifungal effects. Tea tree oil, lemon oil, cinnamon oil, clove oil, and thyme oil, among other EOs from local plants, have positively influenced antibacterial and antioxidant activity, along with expanded cereal shelf lives and enhanced food security. In addition, terpenes and volatile aromatic chemicals, for example, are important EO categories that help food hygiene without affecting quality. For example, EOs might be utilized as an additional preservative to extend the shelf life of grains and cereals because of their numerous effects, including antioxidant and antibacterial properties [106].

The antifungal and anti-aflatoxigenic activities of $5^{\prime}$-hydroxy-aurapten $\left(5^{\prime}\right.$-HA) on A. flavus isolated from nuts (Lotus lalambensis) were investigated. In this study, $5^{\prime}-\mathrm{HA}$ demonstrated a higher antifungal potential against $A$. flavus, having a minimum inhibitory concentration of $62.5 \mathrm{mg} / \mathrm{L}$. It was found that $5^{\prime}-\mathrm{HA}$ had reduced conidia germination 
for $A$. flavus by $60 \%$ at a dose of $40 \mathrm{mg} / \mathrm{mL}$ in the early (A, B, C), middle (L, M, N), and late $(\mathrm{P}, \mathrm{Q}, \mathrm{W})$ stages of the aflatoxin biosynthesis pathway. Moreover, 5'-HA also inhibited the synthesis of aflatoxins, AFB1 and AFB2, by $50 \%$ and $23.3 \%$, respectively. 5'-HA increased the efficacy of enzymatic antioxidants CAT (Catalase) and SOD (Superoxide dismutase) by $56.25 \%$ and $66.66 \%$, respectively. The anti-aflatoxigenic mechanism of $5^{\prime}$-HA is thought to work by increasing the expression profile of the transcription factors atf $A$ and atfB by 2- and 2.5-fold, respectively [107]. Sodium lignosulfonate was found to be an antifungal compound due to its fungistatic activity against $M$. circinelloides, $A$. amoenus, and $P$. solitum. These strains were obtained from spoiled alfalfa hay (Medicago sativa). Sodium lignosulfonate $(\mathrm{NaL})$ had superior preservation properties for the ground high-moisture hay as a substrate [108]. In comparison to spoiled hay, sodium lignosulfonate and PRP had a protective effect against hay proteolysis at a concentration of $0.5 \%$, as assessed by a decrease in ammoniacal nitrogen $\left(\mathrm{NH}_{3}-\mathrm{N}\right)$. Preservatives can prevent plant proteins from deteriorating, retaining their biological worth, according to these studies.

Natamycin is an antifungal medicine with poor solubility that is used in food products to address the base of cheese and sausages. This use does not risk the customer's safety. For beverage preservation, a highly soluble natamycin-cyclodextrin integral membrane was created. This approach results in high drug concentrations that are dangerously above the acceptable limit. In addition to assessing an adequate daily natamycin food intake, researchers must investigate natamycin's impact on the intestinal bacteria as a reservoir for tolerance, which results from the amount of feces in one's system to be abnormally high. Foods having natamycin, introduced and blended uniformly, such as yoghurt, and even the administration of cyclodextrin intercalation to drinks and wine, all contribute to natamycin levels and fecal Candida spp. drug exposure. Candida spp. have established natamycin tolerance in the bowels of persons who have been treated with natamycin for fungal diseases. As a consequence, it is impossible to figure out the likelihood that using natamycin to keep yoghurt and beverages promotes Candida spp. polyene tolerance [109].

The bioactivity of Lactobacillus brevis AM7 during fermentation with bread hydrolysate was evaluated against the fungus (20\% to $70 \%$ ). Using Liquid Chromatography, nine antifungal compounds (with 10-17 amino acid residues and masses spanning 1083.6 to 1980.7 Da) were investigated, all of which were expressed in wheat protein sequences. Bread hydrolysate fermented by L. brevis AM7, non-fermented bread hydrolysate, and a slurry composed of water and bread combination were all used to make bread and compared with conventional wheat bread. Compared to the other pieces of bread, those fermenting hydrolysate (18 and $22 \%$ of the dough weight) had the maximum mold-free shelf life, extending up to 10 days until mold appeared. Moreover, the fermentation hydrolysate had the fewest adverse influences on bread texture, demonstrating biotechnology's beneficial impact and potential [22]. The essential oil of Thymus algeriensis was studied as a possible soft cheese preservative. We devised a novel method for determining the essential oil's ability to preserve soft cheese. During 30 days of storage at $4{ }^{\circ} \mathrm{C}$ with $25 \mathrm{~L}$ of essential oil introduced, there was no contamination of Penicillium aurantiogriseum. Minimum inhibitory concentrations for antifungals varied from 0.01 to $0.04 \mathrm{mg} / \mathrm{mL}$ range. According to the data, the oil was active with a half-maximal inhibitory activity of $0.132 \mathrm{mg} / \mathrm{mL}$. The volatile components in the oil were determined by using gas chromatography, gas chromatographymass spectrometry, and nuclear magnetic resonance spectrometry. The most frequent constituent in the oil was discovered to be carvacrol, which made up $80.9 \%$ of the overall amount, followed by p-cymene (7.7\%) [110].

Both people and the environment are put at risk by chemical preservatives and fungicides. Bio-preservatives, such as lactic acid bacteria (LAB), on the other hand, are efficient, secure, and biodegradable, as well as add adequate beneficial health effects. The antifungal activity of strain RM1 was the highest amongst 23 rod-shaped LAB isolates collected from Egyptian traditionally fermented milk (Rayeb). Strain RM1 was distinguished from genetically similar Lactobacillus species by $16 \mathrm{~S}$ rRNA phylogenetic analysis and distinctive phenotypic traits, indicating that it is a distinct species whereby the name Lactobacillus sp. 
RM1 is suggested. Lactobacillus sp. RM1 cell-free supernatant (CFS) has considerable and broad antifungal effects, mostly against toxigenic fungi and pathogenic bacteria.

Lactobacillus spp. RM1 has antifungal capabilities and the ability to prolong the shelf life of wheat grains, implying that it could be used as a natural food preservative [65]. Antimicrobial substances generated or expelled by LAB can counteract foodborne illnesses, making it a possible alternative to artificial preservatives [111]. Natural preservatives such as LAB are effective, safe, and biodegradable, with added health advantages. LAB is also frequently used as a bio-preservative to increase the shelf life of food products while in storage $[112,113]$. Organic acids, short-chain fatty acids, hydrogen peroxide, reuterin, diacetyl, bacteriocins, and bacteriocin-like inhibitory compounds are some of the antifungal substances produced by LAB [19,65,114], Lactococcus lactis spp. lactis ATCC 19435 inhibits fungal growth and ochratoxin A synthesis in fungal growth conditions $[115,116]$. Antifungal compounds found in LAB have been proven effective in decreasing yeasts and molds that degrade food [117]. Therefore, to eliminate toxic fungus and increase the quality, safety, and shelf life of food and agricultural products, it is critical to look for natural, food-grade antifungal chemicals from LAB.

\section{Major Challenges and Future Prospects}

During the recent decade, tremendous progress has been made in the field of antifungal bio-preservatives. Certain constraints and knowledge gaps, however, must still be addressed. It is also worth noting that commercial cultures are scarce, presumably because the antifungal activity of any given strain is influenced by a variety of physical and chemical factors, the food manufacturing methods, and the strains' ability to generate chemicals in situ in the food product. Health impacts and other safety problems are also key considerations that have yet to be explored for all antifungal strains. For example, safety studies should be included as a routine practice when ascribing an antifungal strain. Such analyses should provide an examination of procured resistance to antibiotics and possible biogenic amine production in compliance with safety considerations. Even though sensory and safety evaluations for antifungal strains are commonly incomplete, trying to highlight the need for further substantiation to protect the safety of using such substances in food matrices, the antifungal bio-additives mentioned are now perfectly suited to a wide range of environments, as demonstrated by their diversified in vivo and in vitro food packaging applications [118-120].

Creating new ready-to-use antifungal combinations, such as Gerez et al. [121] antifungal slurry, would significantly benefit food manufacturers and provide an alternate method for addressing consumer expectations. In addition, extraction and refinement methods must be standardized and quick, sensitive, repeatable, and cost-effective techniques created. In addition, the development of sensitive and quick isolation processes could lead to the discovery of new antifungal chemicals in the future. Transcriptomic methods may become a viable strategy for determining the molecular targets of antifungal compounds generated from bacteria as more genome sequences become accessible. The effects of diverse antifungal drugs should be determined using microarray or other 'omics' technologies, as most of these targets are unknown. Future research should improve our understanding of the genetic mechanisms and metabolic pathways of antifungal synthesis [122].

\section{Conclusions}

An alternative to chemical preservation was highlighted due to rising consumer demands of less processed and more natural foodstuffs while maintaining quality, hygiene, and shelf life. In this perspective, bacteria and fungus and their by-products are natural bioprotective agents that might be used in food to combat fungal deterioration and respond to consumer preferences and legislation. In terms of applicability, the disparity between the series of studies and the number of available microbial cultures shows that more work is needed to make their use in food products easier. Among the most important features is in situ research using tailored fungal targets for antifungal effectiveness testing and 
confirmation. Prior to sale, the bioprotective microorganisms' safety, sensory properties' neutrality, and activity constancy must all be assessed. While antifungal medications have been extensively investigated and generally demonstrated to operate cooperatively, there is still a dearth of understanding about the entire picture of which components are implicated and how they work.

Author Contributions: Conceptualization, B.M. and Y.K.M.; original draft preparation, B.M., A.K.M., S.K. and S.K.M.; writing-review and editing, A.K.M., S.K., L.N. and V.K.; visualization, B.M. and L.N.; supervision, K.-H.B. All authors have read and agreed to the published version of the manuscript.

Funding: This research was funded by PJ015726, Rural Development Administration, Korea.

Acknowledgments: This work was carried out with the support of the Cooperative Research Program for Agriculture Science and Technology Development (Project No. PJ015726), RDA, Korea.

Conflicts of Interest: The authors declare no conflict of interest.

\section{References}

1. Newbold, K.B. Population Growth. In International Encyclopedia of Geography, 15 Volume Set: People, the Earth, Environment and Technology; Richardson, D., Castree, N., Goodchild, M.F., Kobayashi, A., Liu, W., Marston, R.A., Eds.; Major Reference Works; Wiley Online Library: Hoboken, NJ, USA, 2017; pp. 1-6. ISBN 978-0-470-65963-2.

2. Saltmarsh, M.; Insall, L. Food additives and why they are used. In Essential Guide to Food Additives, 4th ed.; Saltmarsh, M., Ed.; The Royal Society of Chemistry: Cambridge, UK, 2013; pp. 1-13. ISBN 978-1-84973-560-5.

3. Setälä, H.; McLean, M.A. Decomposition rate of organic substrates in relation to the species diversity of soil saprophytic fungi. Oecologia 2004, 139, 98-107. [CrossRef] [PubMed]

4. Filtenborg, O.; Frisvad, J.C.; Thrane, U. Moulds in food spoilage. Int. J. Food Microbiol. 1996, 33, 85-102. [CrossRef]

5. Nummer, B.A.; Shrestha, S.; Smith, J. V Survival of Salmonella in a high sugar, low water-activity, peanut butter flavored candy fondant. Food Control 2012, 27, 184-187. [CrossRef]

6. Salaheen, S.; Peng, M.; Biswas, D. Replacement of conventional antimicrobials and preservatives in food production to improve consumer safety and enhance health benefits. In Microbial Food Safety and Preservation Techniques; Rai, V.R., Bai, J.A., Eds.; CRC Press: Boca Raton, FL, USA, 2015; pp. 311-314. ISBN 9780429168291.

7. Pisoschi, A.M.; Pop, A.; Georgescu, C.; Turcuş, V.; Olah, N.K.; Mathe, E. An overview of natural antimicrobials role in food. Eur. J. Med. Chem. 2018, 143, 922-935. [CrossRef] [PubMed]

8. Burt, S. Essential oils: Their antibacterial properties and potential applications in foods-A review. Int. J. Food Microbiol. 2004, 94, 223-253. [CrossRef]

9. Burek, J.; Nutter, D.W. Environmental implications of perishables storage and retailin. Renew. Sustain. Energy Rev. 2020, 133, 110070. [CrossRef]

10. Snyder, A.B.; Churey, J.J.; Worobo, R.W. Association of fungal genera from spoiled processed foods with physicochemical food properties and processing conditions. Food Microbiol. 2019, 83, 211-218. [CrossRef]

11. Leyva Salas, M.; Mounier, J.; Valence, F.; Coton, M.; Thierry, A.; Coton, E. Antifungal microbial agents for food biopreservation-A review. Microorganisms 2017, 5, 37. [CrossRef]

12. Pennington, J.A.T.; Fisher, R.A. Classification of fruits and vegetables. J. Food Compos. Anal. 2009, 22, S23-S31. [CrossRef]

13. Abbas, E.; Osman, A.; Sitohy, M. Biochemical control of Alternaria tenuissima infecting postharvest fig fruit by chickpea vicilin. J. Sci. Food Agric. 2020, 100, 2889-2897. [CrossRef]

14. Majumdar, A.; Pradhan, N.; Sadasivan, J.; Acharya, A.; Ojha, N.; Babu, S.; Bose, S. Food degradation and foodborne diseases: A microbial approach. In Microbial Contamination and Food Degradation; Elsevier: Amsterdam, The Netherlands, 2018 ; pp. 109-148.

15. Odeyemi, O.A.; Alegbeleye, O.O.; Strateva, M.; Stratev, D. Understanding spoilage microbial community and spoilage mechanisms in foods of animal origin. Compr. Rev. food Sci. food Saf. 2020, 19, 311-331. [CrossRef]

16. Señorans, F.J.; Ibáñez, E.; Cifuentes, A. New trends in food processing. Crit. Rev. Food Sci. Nutr. 2003, 43, 507-526. [CrossRef]

17. Sayed, A.M.; Hassan, M.H.A.; Alhadrami, H.A.; Hassan, H.M.; Goodfellow, M.; Rateb, M.E. Extreme environments: Microbiology leading to specialized metabolites. J. Appl. Microbiol. 2020, 128, 630-657. [CrossRef]

18. Rouse, S.; Harnett, D.; Vaughan, A.; Sinderen, D. van Lactic acid bacteria with potential to eliminate fungal spoilage in foods. J. Appl. Microbiol. 2008, 104, 915-923. [CrossRef] [PubMed]

19. Yang, E.J.; Chang, H.C. Purification of a new antifungal compound produced by Lactobacillus plantarum AF1 isolated from kimchi. Int. J. Food Microbiol. 2010, 139, 56-63. [CrossRef]

20. Prema, P.; Smila, D.; Palavesam, A.; Immanuel, G. Production and characterization of an antifungal compound (3-phenyllactic acid) produced by Lactobacillus plantarum strain. Food Bioprocess Technol. 2010, 3, 379-386. [CrossRef]

21. Sadiq, F.A.; Yan, B.; Tian, F.; Zhao, J.; Zhang, H.; Chen, W. Lactic acid bacteria as antifungal and anti-mycotoxigenic agents: A comprehensive review. Compr. Rev. Food Sci. Food Saf. 2019, 18, 1403-1436. [CrossRef] [PubMed] 
22. Nionelli, L.; Wang, Y.; Pontonio, E.; Immonen, M.; Rizzello, C.G.; Maina, H.N.; Katina, K.; Coda, R. Antifungal effect of bioprocessed surplus bread as ingredient for bread-making: Identification of active compounds and impact on shelf-life. Food Control 2020, 118, 107437. [CrossRef]

23. Álvarez, M.; Andrade, M.J.; García, C.; Rondán, J.J.; Núñez, F. Effects of preservative agents on quality attributes of dry-cured fermented sausages. Foods 2020, 9, 1505. [CrossRef] [PubMed]

24. Salas, M.L.; Lemaitre, M.; Garric, G.; Harel-Oger, M.; Lê, S.; Mounier, J.; Valence-Bertel, F.; Coton, E.; Thierry, A. Antifungal lactic acid bacteria combinations as biopreservation tool in dairy products. In Proceedings of the 5ième Rencontre Nutrition Alimnetation Métabolisme Santé, Rennes, France, 23 October 2019.

25. Mani-López, E.; García, H.S.; López-Malo, A. Organic acids as antimicrobials to control Salmonella in meat and poultry products. Food Res. Int. 2012, 45, 713-721. [CrossRef]

26. Crowley, S.; Mahony, J.; van Sinderen, D. Broad-spectrum antifungal-producing lactic acid bacteria and their application in fruit models. Folia Microbiol. 2013, 58, 291-299. [CrossRef] [PubMed]

27. Buehler, A.J.; Martin, N.H.; Boor, K.J.; Wiedmann, M. Evaluation of biopreservatives in Greek yogurt to inhibit yeast and mold spoilage and development of a yogurt spoilage predictive model. J. Dairy Sci. 2018, 101, 10759-10774. [CrossRef] [PubMed]

28. Schwenninger, S.M.; Lacroix, C.; Truttmann, S.; Jans, C.; Spoerndli, C.; Bigler, L.; Meile, L. Characterization of low-molecularweight antiyeast metabolites produced by a food-protective Lactobacillus-Propionibacterium coculture. J. Food Prot. 2008, 71, 2481-2487. [CrossRef]

29. Wang, Z.; Zhong, T.; Chen, K.; Du, M.; Chen, G.; Chen, X.; Wang, K.; Zalán, Z.; Takács, K.; Kan, J. Antifungal activity of volatile organic compounds produced by Pseudomonas fluorescens ZX and potential biocontrol of blue mold decay on postharvest citrus. Food Control 2021, 120, 107499. [CrossRef]

30. Sun, Y.; Wang, Y.; Han, L.R.; Zhang, X.; Feng, J.T. Antifungal activity and action mode of cuminic acid from the seeds of Cuminum cyminum L. against Fusarium oxysporum f. sp. niveum (FON) causing Fusarium wilt on watermelon. Molecules 2017, $22,2053$. [CrossRef]

31. Luz, C.; Carbonell, R.; Quiles, J.M.; Torrijos, R.; de Melo Nazareth, T.; Mañes, J.; Meca, G. Antifungal activity of peracetic acid against toxigenic fungal contaminants of maize and barley at the postharvest stage. LWT 2021, 148, 111754. [CrossRef]

32. Haddoudi, I.; Cabrefiga, J.; Mora, I.; Mhadhbi, H.; Montesinos, E.; Mrabet, M. Biological control of Fusarium wilt caused by Fusarium equiseti in Vicia faba with broad spectrum antifungal plant-associated Bacillus spp. Biol. Control 2021, 160, 104671. [CrossRef]

33. Salas, M.L.; Mounier, J.; Maillard, M.-B.; Valence, F.; Coton, E.; Thierry, A. Identification and quantification of natural compounds produced by antifungal bioprotective cultures in dairy products. Food Chem. 2019, 301, 125260. [CrossRef]

34. Adedokun, E.O.; Rather, I.A.; Bajpai, V.K.; Park, Y.-H. Biocontrol efficacy of Lactobacillus fermentum YML014 against food spoilage moulds using the tomato puree model. Front. Life Sci. 2016, 9, 64-68. [CrossRef]

35. Alía, A.; Andrade, M.J.; Rodríguez, A.; Reyes-Prieto, M.; Bernáldez, V.; Córdoba, J.J. Identification and control of moulds responsible for black spot spoilage in dry-cured ham. Meat Sci. 2016, 122, 16-24. [CrossRef] [PubMed]

36. Jung, S.; Hwang, H.; Lee, J.-H. Effect of lactic acid bacteria on phenyllactic acid production in kimchi. Food Control 2019, 106, 106701. [CrossRef]

37. Xu, J.-J.; Sun, J.-Z.; Si, K.-L.; Guo, C.-F. 3-Phenyllactic acid production by Lactobacillus crustorum strains isolated from naturally fermented vegetables. LWT 2021, 111780. [CrossRef]

38. Guan, J.; Han, C.; Guan, Y.; Zhang, S.; Yun, J.; Yao, S. Optimizational production of phenyllactic acid by a Lactobacillus buchneri strain via uniform design with overlay sampling methodology. Chin. J. Chem. Eng. 2019, 27, 418-425. [CrossRef]

39. Amiri, S.; Aghamirzaei, M.; Mostashari, P.; Sarbazi, M.; Tizchang, S.; Madahi, H. The impact of biotechnology on dairy industry. In Microbial Biotechnology in Food and Health; Ray, R.C., Ed.; Academic Press: Cambridge, UK, 2021; pp. 53-79. ISBN 9780128198131.

40. Chaudhari, S.S.; Gokhale, D. V Phenyllactic acid: A potential antimicrobial compound in lactic acid bacteria. J. Bacteriol. Mycol. Open Access 2016, 2, 121-125.

41. Jung, S.; Woo, C.; Fugaban, J.I.I.; Vazquez Bucheli, J.E.; Holzapfel, W.H.; Todorov, S.D. Bacteriocinogenic potential of Bacillus amyloliquefaciens isolated from Kimchi, a traditional Korean fermented cabbage. Probiotics Antimicrob. Proteins 2021, 13, 1195-1212. [CrossRef]

42. Huang, C.-H.; Chen, W.-C.; Gao, Y.-H.; Hsiao, H.-I.; Pan, C.-L. Production of phenyllactic acid from Porphyra residues by Lactic Acid bacterial fermentation. Processes 2021, 9, 678. [CrossRef]

43. Dung, V.K.; Ngoc, N.N.; Dung, L.S.; Hien, V.T.N. Collection of phenyllactic acid from a strain of Lactobacillus sp. and application in agricultural products preservation. Vietnam. J. Food Control 2021, 4, 22-33.

44. Pradhan, S.; Ananthanarayan, L.; Prasad, K.; Bhatnagar-Mathur, P. Anti-fungal activity of lactic acid bacterial isolates against aflatoxigenic fungi inoculated on peanut kernels. LWT 2021, 143, 111104. [CrossRef]

45. Zhao, Y.; Wu, C.; Zhu, Y.; Zhou, C.; Xiong, Z.; Eweys, A.S.; Zhou, H.; Dong, Y.; Xiao, X. Metabolomics strategy for revealing the components in fermented barley extracts with Lactobacillus plantarum dy-1. Food Res. Int. 2021, 139, 109808. [CrossRef] [PubMed]

46. Chen, H.; Ju, H.; Wang, Y.; Du, G.; Yan, X.; Cui, Y.; Yuan, Y.; Yue, T. Antifungal activity and mode of action of Lactic acid bacteria isolated from Kefir against Penicillium expansum. Food Control 2021, 108274. [CrossRef] 
47. Valencia-Hernandez, L.J.; Lopez-Lopez, K.; Gomez-Lopez, E.D.; SERNACOCK, L.; Aguilar, C.N. In-vitro assessment for the control of Fusarium species using a lactic acid bacterium isolated from yellow pitahaya (Selenicereus megalanthus (K. Schum. Ex Vaupel Moran)). J. Integr. Agric. 2021, 20, 159-167. [CrossRef]

48. Alaoui, K.; Chafik, Z.; Arabi, M.; Abouloifa, H.; Asehraou, A.; Chaoui, J.; Kharmach, E.-Z. In vitro antifungal activity of Lactobacillus against potato Late blight Phytophthora infestans. Mater. Today Proc. 2021, 45, 7725-7733. [CrossRef]

49. Abouloifa, H.; Gaamouche, S.; Rokni, Y.; Hasnaoui, I.; Bellaouchi, R.; Ghabbour, N.; Karboune, S.; Brasca, M.; D’Hallewin, G.; Ben Salah, R.; et al. Antifungal activity of probiotic Lactobacillus strains isolated from natural fermented green olives and their application as food bio-preservative. Biol. Control 2021, 152, 104450. [CrossRef]

50. Makki, G.M.; Kozak, S.M.; Jencarelli, K.G.; Alcaine, S.D. Evaluation of the efficacy of commercial protective cultures to inhibit mold and yeast in cottage cheese. J. Dairy Sci. 2021, 104, 2709-2718. [CrossRef] [PubMed]

51. Schmidt, M.; Lynch, K.M.; Zannini, E.; Arendt, E.K. Fundamental study on the improvement of the antifungal activity of Lactobacillus reuteri R29 through increased production of phenyllactic acid and reuterin. Food Control 2018, 88, 139-148. [CrossRef]

52. Bustos, A.Y.; de Valdez, G.F.; Gerez, C.L. Optimization of phenyllactic acid production by Pediococcus acidilactici CRL 1753. Application of the formulated bio-preserver culture in bread. Biol. Control 2018, 123, 137-143. [CrossRef]

53. Luz, C.; D’Opazo, V.; Quiles, J.M.; Romano, R.; Mañes, J.; Meca, G. Biopreservation of tomatoes using fermented media by lactic acid bacteria. LWT 2020, 130, 109618. [CrossRef]

54. Li, X.; Ning, Y.; Liu, D.; Yan, A.; Wang, Z.; Wang, S.; Miao, M.; Zhu, H.; Jia, Y. Metabolic mechanism of phenyllactic acid naturally occurring in Chinese pickles. Food Chem. 2015, 186, 265-270. [CrossRef] [PubMed]

55. Quattrini, M.; Liang, N.; Fortina, M.G.; Xiang, S.; Curtis, J.M.; Gänzle, M. Exploiting synergies of sourdough and antifungal organic acids to delay fungal spoilage of bread. Int. J. Food Microbiol. 2019, 302, 8-14. [CrossRef]

56. Dallagnol, A.M.; Bustos, A.Y.; Martos, G.I.; de Valdez, G.F.; Gerez, C.L. Antifungal and antimycotoxigenic effect of Lactobacillus plantarum CRL 778 at different water activity values. Rev. Argent. Microbiol. 2019, 51, 164-169. [CrossRef]

57. Ruggirello, M.; Nucera, D.; Cannoni, M.; Peraino, A.; Rosso, F.; Fontana, M.; Cocolin, L.; Dolci, P. Antifungal activity of yeasts and lactic acid bacteria isolated from cocoa bean fermentations. Food Res. Int. 2019, 115, 519-525. [CrossRef]

58. Solano, R.J.; Sierra, C.A.; Murillo, M.Á. Antifungal activity of LDPE/lauric acid films against Colletotrichum tamarilloi. Food Packag. Shelf Life 2020, 24, 100495. [CrossRef]

59. Ouiddir, M.; Bettache, G.; Salas, M.L.; Pawtowski, A.; Donot, C.; Brahimi, S.; Mabrouk, K.; Coton, E.; Mounier, J. Selection of Algerian lactic acid bacteria for use as antifungal bioprotective cultures and application in dairy and bakery products. Food Microbiol. 2019, 82, 160-170. [CrossRef] [PubMed]

60. Garnier, L.; Penland, M.; Thierry, A.; Maillard, M.-B.; Jardin, J.; Coton, M.; Salas, M.L.; Coton, E.; Valence, F.; Mounier, J. Antifungal activity of fermented dairy ingredients: Identification of antifungal compounds. Int. J. Food Microbiol. 2020, 322, 108574. [CrossRef] [PubMed]

61. Liang, N.; Dacko, A.; Tan, A.K.; Xiang, S.; Curtis, J.M.; Gänzle, M.G. Structure-function relationships of antifungal monohydroxy unsaturated fatty acids (HUFA) of plant and bacterial origin. Food Res. Int. 2020, 134, 109237. [CrossRef]

62. Souza, J.L.S.; da Silva, A.F.; Carvalho, P.H.A.; Pacheco, B.S.; Pereira, C.M.P.; Lund, R.G. Aliphatic fatty acids and esters: Inhibition of growth and exoenzyme production of Candida, and their cytotoxicity in vitro: Anti-candida effect and cytotoxicity of fatty acids and esters. Arch. Oral Biol. 2014, 59, 880-886. [CrossRef]

63. Elsherbiny, E.A.; Dawood, D.H.; Safwat, N.A. Antifungal action and induction of resistance by $\beta$-aminobutyric acid against Penicillium digitatum to control green mold in orange fruit. Pestic. Biochem. Physiol. 2021, 171, 104721. [CrossRef]

64. Pinilla, C.M.B.; Thys, R.C.S.; Brandelli, A. Antifungal properties of phosphatidylcholine-oleic acid liposomes encapsulating garlic against environmental fungal in wheat bread. Int. J. Food Microbiol. 2019, 293, 72-78. [CrossRef]

65. Shehata, M.G.; Badr, A.N.; El Sohaimy, S.A.; Asker, D.; Awad, T.S. Characterization of antifungal metabolites produced by novel lactic acid bacterium and their potential application as food biopreservatives. Ann. Agric. Sci. 2019, 64, 71-78. [CrossRef]

66. Sahu, M.; Dwivedi, V. Studies on Lactobacillus bacteriocin for production and characterization against some pathogenic and food spoilage bacteria. Int. J. Curr. Res. Acad. Rev. 2021, 9, 1-12.

67. Vimont, A.; Fernandez, B.; Ahmed, G.; Fortin, H.-P.; Fliss, I. Quantitative antifungal activity of reuterin against food isolates of yeasts and moulds and its potential application in yogurt. Int. J. Food Microbiol. 2019, 289, 182-188. [CrossRef] [PubMed]

68. El-Ziney, M.G.; van den Tempel, T.; Debevere, J.; Jakobsen, M. Application of Reuterin produced by Lactobacillus reuteri 12002 for meat decontamination and preservation. J. Food Prot. 1999, 62, 257-261. [CrossRef] [PubMed]

69. Ortiz-Rivera, Y.; Sánchez-Vega, R.; Gutiérrez-Méndez, N.; León-Félix, J.; Acosta-Muñiz, C.; Sepulveda, D.R. Production of reuterin in a fermented milk product by Lactobacillus reuteri: Inhibition of pathogens, spoilage microorganisms, and lactic acid bacteria. $J$. Dairy Sci. 2017, 100, 4258-4268. [CrossRef]

70. Mishra, K.A.; Choi, J.; Choi, S.-J.; Baek, K.-H. Cyclodipeptides: An overview of their biosynthesis and biological activity. Molecules 2017, 22, 1796. [CrossRef]

71. Kumar, S.N.; Nambisan, B.; Mohandas, C. Purification and identification of two antifungal cyclic dipeptides from Bacillus cereus subsp. thuringiensis associated with a rhabditid entomopathogenic nematode especially against Fusarium oxysporum. J. Enzyme Inhib. Med. Chem. 2014, 29, 190-197. [CrossRef] [PubMed]

72. Kwak, M.-K.; Liu, R.; Kim, M.-K.; Moon, D.; Kim, A.H.; Song, S.-H.; Kang, S.-O. Cyclic dipeptides from lactic acid bacteria inhibit the proliferation of pathogenic fungi. J. Microbiol. 2014, 52, 64-70. [CrossRef] 
73. Bayisa, R.A.; Cho, J.Y.; Kim, K.Y. Purification and identification of a new antifungal dipeptide from Bacillus velezensis AR1 culture supernatant. Pest Manag. Sci. 2021, 77, 775-779. [CrossRef]

74. Adibi, A.; Rees, E.R.; McCarley, S.; Sica, V.P.; Oberlies, N.H. Characterization and isolation of peptide metabolites of an antifungal bacterial isolate identified as Bacillus amyloliquefaciens subspecies plantarum strain FZB42. J. Microbiol. Biotechnol. Food Sci. 2021, 2021, 1309-1313. [CrossRef]

75. Deepa, S.; Sathish, T.; Vinithkumar, N.V.; Limna Mol, V.P.; Kirubagaran, R. Distribution and diversity of macrofoulers in the coastal areas of Port Blair, Andaman and Nicobar Islands. Int. J. Environ. Res. 2015, 9, 1315-1324.

76. Sellamani, M.; Kalagatur, N.K.; Siddaiah, C.; Mudili, V.; Krishna, K.; Natarajan, G.; Rao Putcha, V.L. Antifungal and zearalenone inhibitory activity of Pediococcus pentosaceus isolated from dairy products on Fusarium graminearum. Front. Microbiol. 2016, 7, 890. [CrossRef] [PubMed]

77. Gajbhiye, M.; Kapadnis, B. Lactococcus lactis subsp. cremoris of plant origin produces antifungal Cyclo-(Leu-Pro) and tetradecanoic acid. Indian J. Microbiol. 2021, 61, 74-80. [CrossRef]

78. Tanaka, E.; Hosoe, T.; Degawa, Y.; Kolařík, M. Revision of the genus Aciculosporium (Clavicipitaceae) with a description of a new species on wavyleaf basketgrass, and proline-containing cyclic dipeptide production by A. take. Mycoscience 2021, MYC527. [CrossRef]

79. Qader, M.M.; Hamed, A.A.; Soldatou, S.; Abdelraof, M.; Elawady, M.E.; Hassane, A.S.I.; Belbahri, L.; Ebel, R.; Rateb, M.E. Antimicrobial and antibiofilm activities of the fungal metabolites isolated from the marine endophytes Epicoccum nigrum M13 and Alternaria alternata 13A. Mar. Drugs 2021, 19, 232. [CrossRef] [PubMed]

80. Yu, H.; Wang, J.; Li, X.; Quan, C. Effect of the environmental factors on diketopiperazine cyclo (Pro-Phe) production and antifungal activity of Bacillus amyloliquefaciens Q-426. Biologia 2021, 76, 1789-1795. [CrossRef]

81. Liu, R.; Zhang, H.; Wu, W.; Li, H.; An, Z.; Zhou, F. C7-prenylation of tryptophan-containing cyclic dipeptides by 7-dimethylallyl tryptophan synthase significantly increases the anticancer and antimicrobial activities. Molecules 2020, 25, 3676. [CrossRef] [PubMed]

82. Ebrahimi, M.; Sadeghi, A.; Mortazavi, S.A. The use of cyclic dipeptide producing LAB with potent anti-aflatoxigenic capability to improve techno-functional properties of clean-label bread. Ann. Microbiol. 2020, 70, 24. [CrossRef]

83. Qiu, S.; Avula, B.; Guan, S.; Ravu, R.R.; Wang, M.; Zhao, J.; Khan, I.A.; Hinchee, M.; Li, X.-C. Identification of fusaricidins from the antifungal microbial strain Paenibacillus sp. MS2379 using ultra-high performance liquid chromatography coupled to quadrupole time-of-flight mass spectrometry. J. Chromatogr. A 2019, 1586, 91-100. [CrossRef] [PubMed]

84. Kwak, M.-K.; Liu, R.; Kang, S.-O. Antimicrobial activity of cyclic dipeptides produced by Lactobacillus plantarum LBP-K10 against multidrug-resistant bacteria, pathogenic fungi, and influenza A virus. Food Control 2018, 85, 223-234. [CrossRef]

85. Borthwick, A.D.; Da Costa, N.C. 2,5-diketopiperazines in food and beverages: Taste and bioactivity. Crit. Rev. Food Sci. Nutr. 2017, 57, 718-742. [CrossRef]

86. Kumar, N.; Mohandas, C.; Nambisan, B.; Kumar, D.R.S.; Lankalapalli, R.S. Isolation of proline-based cyclic dipeptides from Bacillus sp. N strain associated with rhabitid entomopathogenic nematode and its antimicrobial properties. World J. Microbiol. Biotechnol. 2013, 29, 355-364. [CrossRef]

87. Dover, S.E.; Aroutcheva, A.A.; Faro, S.; Chikindas, M.L. Natural antimicrobials and their role in vaginal health: A short review. Int. J. Probiotics Prebiotics 2008, 3, 219. [PubMed]

88. Ahmad, H.; Matsubara, Y. Suppression of anthracnose in strawberry using water extracts of lamiaceae herbs and identification of antifungal metabolites. Hortic. J. 2020, 89, 359-366. [CrossRef]

89. Arora, D.S.; Kaur, J. Antimicrobial activity of spices. Int. J. Antimicrob. Agents 1999, 12, 257-262. [CrossRef]

90. Crowley, S.; Mahony, J.; van Sinderen, D. Current perspectives on antifungal lactic acid bacteria as natural bio-preservatives. Trends Food Sci. Technol. 2013, 33, 93-109. [CrossRef]

91. Gajbhiye, M.H.; Kapadnis, B.P. Antifungal-activity-producing lactic acid bacteria as biocontrol agents in plants. Biocontrol Sci. Technol. 2016, 26, 1451-1470. [CrossRef]

92. Li, J.; Wang, W.; Xu, S.X.; Magarvey, N.A.; McCormick, J.K. Lactobacillus reuteri-produced cyclic dipeptides quench agr-mediated expression of toxic shock syndrome toxin-1 in staphylococci. Proc. Natl. Acad. Sci. USA 2011, 108, 3360-3365. [CrossRef] [PubMed]

93. Engelhardt, T.; Albano, H.; Kiskó, G.; Mohácsi-Farkas, C.; Teixeira, P. Antilisterial activity of bacteriocinogenic Pediococcus acidilactici HA6111-2 and Lactobacillus plantarum ESB 202 grown under $\mathrm{pH}$ and osmotic stress conditions. Food Microbiol. 2015, 48, 109-115. [CrossRef] [PubMed]

94. Rhoads, D.M.; Umbach, A.L.; Subbaiah, C.C.; Siedow, J.N. Mitochondrial reactive oxygen species. Contribution to oxidative stress and interorganellar signaling. Plant Physiol. 2006, 141, 357-366. [CrossRef] [PubMed]

95. Desbois, A.P.; Smith, V.J. Antibacterial free fatty acids: Activities, mechanisms of action and biotechnological potential. Appl. Microbiol. Biotechnol. 2010, 85, 1629-1642. [CrossRef] [PubMed]

96. Rajanikar, R.V.; Nataraj, B.H.; Naithani, H.; Ali, S.A.; Panjagari, N.R.; Behare, P. V Phenyllactic Acid: A green compound for food biopreservation. Food Control 2021, 128, 108184. [CrossRef]

97. Kadyan, S.; Pradhan, D. Antifungal Lactic Acid Bacteria (LAB): Potential use in food systems. In Novel Strategies to Improve Shelf-Life and Quality of Foods; Mishra, S.K., Goyal, M.R., Eds.; Apple Academic Press: New York, NY, USA, 2020; pp. 73-94. ISBN 100301027X. 
98. Svanström, Å.; Boveri, S.; Boström, E.; Melin, P. The lactic acid bacteria metabolite phenyllactic acid inhibits both radial growth and sporulation of filamentous fungi. BMC Res. Notes 2013, 6, 464. [CrossRef] [PubMed]

99. Singh, O.; Khanam, Z.; Misra, N.; Srivastava, M.K. Chamomile (Matricaria chamomilla L.): An overview. Pharmacogn. Rev. 2011, 5, 82. [CrossRef] [PubMed]

100. Liu, L.-Y.; Li, Z.-H.; Ding, Z.-H.; Dong, Z.-J.; Li, G.-T.; Li, Y.; Liu, J.-K. Meroterpenoid pigments from the basidiomycete Albatrellus ovinus. J. Nat. Prod. 2013, 76, 79-84. [CrossRef]

101. Gupta, P.; Gupta, S.; Sharma, M.; Kumar, N.; Pruthi, V.; Poluri, K.M. Effectiveness of phytoactive molecules on transcriptional expression, biofilm matrix, and cell wall components of Candida glabrata and its clinical isolates. ACS Omega 2018, 3, 12201-12214. [CrossRef]

102. Zillich, O.V.; Schweiggert-Weisz, U.; Eisner, P.; Kerscher, M. Polyphenols as active ingredients for cosmetic products. Int. J. Cosmet. Sci. 2015, 37, 455-464. [CrossRef]

103. Ivanova, A.; Ivanova, K.; Tzanov, T. Inhibition of quorum-sensing: A new paradigm in controlling bacterial virulence and biofilm formation. In Biotechnological Applications of Quorum Sensing Inhibitors; Kalia, V.C., Ed.; Springer: Singapore, 2018 ; pp. 3-21.

104. Tjia, J.A. Journey into C. albicans Biofilms: Proteomic and Functional Genomic Approaches to Uncovering Mechanisms of Adherence; University of Toronto: Toronto, ON, Canada, 2016.

105. Krishnamoorthy, R.; Gassem, M.A.; Athinarayanan, J.; Periyasamy, V.S.; Prasad, S.; Alshatwi, A.A. Antifungal activity of nanoemulsion from Cleome viscosa essential oil against foodborne pathogenic Candida albicans. Saudi J. Biol. Sci. 2021, 28, $286-293$. [CrossRef]

106. Bhavaniramya, S.; Vishnupriya, S.; Al-Aboody, M.S.; Vijayakumar, R.; Baskaran, D. Role of essential oils in food safety: Antimicrobial and antioxidant applications. Grain Oil Sci. Technol. 2019, 2, 49-55. [CrossRef]

107. Ali, E.M.; Alkuwayti, M.A.; Aldayel, M.F.; Abdallah, B.M. Coumarin derivative, 5'-hydroxy-auraptene, extracted from Lotus lalambensis, displays antifungal and anti-aflatoxigenic activities against Aspergillus flavus. J. King Saud Univ.-Sci. 2021, $33,101216$. [CrossRef]

108. Reyes, D.C.; Annis, S.L.; Rivera, S.A.; Leon-Tinoco, A.Y.; Wu, C.; Perkins, L.B.; Perry, J.J.; Ma, Z.X.; Knight, C.W.; Castillo, M.S.; et al. In vitro screening of technical lignins to determine their potential as hay preservatives. J. Dairy Sci. 2020, 103, 6114-6134. [CrossRef]

109. Dalhoff, A.A.H.; Levy, S.B. Does use of the polyene natamycin as a food preservative jeopardise the clinical efficacy of amphotericin B? A word of concern. Int. J. Antimicrob. Agents 2015, 45, 564-567. [CrossRef]

110. Bukvicki, D.; Giweli, A.; Stojkovic, D.; Vujisic, L.; Tesevic, V.; Nikolic, M.; Sokovic, M.; Marin, P.D. Cheese supplemented with Thymus algeriensis oil, a potential natural food preservative. J. Dairy Sci. 2018, 101, 3859-3865. [CrossRef] [PubMed]

111. Nebbia, S.; Lamberti, C.; Lo Bianco, G.; Cirrincione, S.; Laroute, V.; Cocaign-Bousquet, M.; Cavallarin, L.; Giuffrida, M.G.; Pessione, E. Antimicrobial potential of food Lactic Acid Bacteria: Bioactive peptide decrypting from caseins and bacteriocin production. Microorganisms 2021, 9, 65. [CrossRef]

112. Shehata, M.G.; Badr, A.N.; El Sohaimy, S.A. Novel antifungal bacteriocin from Lactobacillus paracasei KC39 with anti-mycotoxigenic properties. Biosci. Res. 2018, 15, 4171-4183.

113. Ahmad Rather, I.; Seo, B.J.; Rejish Kumar, V.J.; Choi, U.; Choi, K.; Lim, J.H.; Park, Y. Isolation and characterization of a proteinaceous antifungal compound from Lactobacillus plantarum YML 007 and its application as a food preservative. Lett. Appl. Microbiol. 2013, 57, 69-76. [CrossRef] [PubMed]

114. Ryu, E.H.; Yang, E.J.; Woo, E.R.; Chang, H.C. Purification and characterization of antifungal compounds from Lactobacillus plantarum HD1 isolated from kimchi. Food Microbiol. 2014, 41, 19-26. [CrossRef]

115. Badr, A.N.; Abdel-Fatah, S.M.; Sree, Y.H.A.; Amra, H.A. Mycotoxigenic fungi and mycotoxins in Egyptian barley under climate changes. Res. J. Environ. Toxicol. 2017, 11, 1-10. [CrossRef]

116. Badr, A.N.; Nada, F.; Shehata, M.G.; Amra, H.A. Anti-mycotic and anti-mycotoxigenic properties of Egyptian dill. J. Appl. Sci. 2017, 17, 184-195. [CrossRef]

117. Schnürer, J.; Magnusson, J. Antifungal lactic acid bacteria as biopreservatives. Trends Food Sci. Technol. 2005, 16, 70-78. [CrossRef]

118. Manso, S.; Becerril, R.; Nerín, C.; Gómez-Lus, R. Influence of pH and temperature variations on vapor phase action of an antifungal food packaging against five mold strains. Food Control 2015, 47, 20-26. [CrossRef]

119. Solano, A.C.V.; de Rojas Gante, C. Two different processes to obtain antimicrobial packaging containing natural oils. Food Bioprocess Technol. 2012, 5, 2522-2528. [CrossRef]

120. Becerril, R.; Manso, S.; Nerin, C.; Gómez-Lus, R. Antimicrobial activity of Lauroyl Arginate Ethyl (LAE), against selected foodborne bacteria. Food Control 2013, 32, 404-408. [CrossRef]

121. Gerez, C.L.; Torino, M.I.; Obregozo, M.D.; de Valdez, G.F. A ready-to-use antifungal starter culture improves the shelf life of packaged bread. J. Food Prot. 2010, 73, 758-762. [CrossRef] [PubMed]

122. Domínguez, Á.; Muñoz, E.; López, M.C.; Cordero, M.; Martínez, J.P.; Viñas, M. Transcriptomics as a tool to discover new antibacterial targets. Biotechnol. Lett. 2017, 39, 819-828. [CrossRef] [PubMed] 